\title{
Semi-domesticated dogs as a potential reservoir for zoonotic hookworms in Bangkok, Thailand
}

\author{
Jutamas Wongwigkan ${ }^{1,2,3}$ and Tawin Inpankaew $1,2,3$ (D)
}

1. Center for Agricultural Biotechnology, Kasetsart University, Kamphaeng Saen Campus, Nakhon Pathom, Thailand;

2. Center of Excellence on Agricultural Biotechnology: (AG-BIO/PERDO-CHE), Bangkok, Thailand; 3. Department of Parasitology, Faculty of Veterinary Medicine, Kasetsart University, Bangkok, Thailand.

Corresponding author: Tawin Inpankaew, e-mail: fvettwi@ku.ac.th

Co-author: JW: jutamas.wongw@ku.th

Received: 12-12-2019, Accepted: 13-04-2020, Published online: 16-05-2020

doi: www.doi.org/10.14202/vetworld.2020.909-915 How to cite this article: Wongwigkan J, Inpankaew T (2020) Semi-domesticated dogs as a potential reservoir for zoonotic hookworms in Bangkok, Thailand, Veterinary World, 13(5): 909-915.

\begin{abstract}
Background and Aim: Hookworms are parasitic nematodes that live in the small intestine of their mammalian hosts including humans, dogs, and cats. This study was conducted to determine the prevalence and perform genetic characterization of hookworms using molecular techniques and to elucidate the risk factors associated with hookworm infections among semi-domesticated dogs residing in temples in the Bangkok Metropolitan Area, Thailand.

Materials and Methods: A total of 500 fecal samples were collected from semi-domesticated dogs from 91 temples in 48 districts of Bangkok. DNA was extracted and screened using internal transcribed spacer polymerase chain reaction-restriction fragment length polymorphism. In addition, samples positive for Ancylostoma ceylanicum were further characterized at the haplotype level based on the analysis of the mitochondrial cytochrome oxidase-1 gene (coxl).

Results: The prevalence of hookworm infections in semi-domesticated dogs was $6.2 \%$ (31/500). Hookworm infections were detected in temple-community dogs in 12 of 48 districts (25.0\%), with Bang Khen and Lak Si districts having the highest proportion of infected dogs (22.6\%). Regarding molecular characterization of hookworm species, 21 positive samples (67.74\%) were infected with A. ceylanicum and 10 (32.26\%) with Ancylostoma caninum. Characterization of cox 1 in A. ceylanicum isolates revealed the presence of a mixture of human and dog isolates.
\end{abstract}

Conclusion: Semi-domesticated dogs act as a potential source of hookworm infections for human and animal populations in Bangkok, Thailand.

Keywords: Bangkok, hookworm, semi-domesticated dogs, Thailand.

\section{Introduction}

Hookworms are parasitic nematodes that live in the small intestine of their mammalian hosts such as humans, dogs, and cats. Helminthiasis, which is caused by hookworms, is the most common soil-transmitted infection and neglected tropical disease [1,2]. The major clinical signs of this disease are chronic intestinal blood loss, iron deficiency anemia, and cutaneous larva migrans. The hookworm species that cause the majority of infections in humans are Necator americanus and Ancylostoma duodenale, whereas those responsible for causing the majority of infections in dog are Ancylostoma caninum and Ancylostoma ceylanicum [3]. Furthermore, A. ceylanicum is a potential zoonotic hookworm and can infect cats and dogs throughout Asia. Hookworm infections are common throughout sub-Saharan Africa, America, South China, and Southeast Asia [4,5]. Numerous cases of

Copyright: Wongwigkan and Inpankaew. Open Access. This article is distributed under the terms of the Creative Commons Attribution 4.0 International License (http://creativecommons. org/licenses/by/4.0/), which permits unrestricted use, distribution, and reproduction in any medium, provided you give appropriate credit to the original author(s) and the source, provide a link to the Creative Commons license, and indicate if changes were made. The Creative Commons Public Domain Dedication waiver (http:// creativecommons.org/publicdomain/zero/1.0/) applies to the data made available in this article, unless otherwise stated. hookworm infections in domestic dogs and cats have been reported in several countries such as the East Coast of the United States [6], Northern Australia tropical rainforests [7], India [8], Cambodia [9], Laos [10], and Malaysia [11,12].

In Thailand, three studies have reported the prevalence of hookworm infections including a report on dogs in an animal refuge in Nakhon Nayok (prevalence $=30.6 \%$ ) [13], a study on dogs in Bangkok (Thailand) temples (prevalence $=58.0 \%$ ) [14], and another study on dogs in lower Northern Thailand (prevalence $=21.3 \%$ ) [15]. Therefore, these and the above-mentioned reports demonstrate that dogs and cats likely serve as reservoirs for hookworms causing infections in humans. In addition to being commonly found in domestic dogs and cats, hookworms comprising at least 68 species have been reported to infect wild animals [16,17], and A. ceylanicum infections have been reported in wild canines [18].

There are numerous dogs, particularly stray and semi-domesticated dogs, in Thailand whose population is continually increasing. As reported by the Bureau of Disease Control and Veterinary Services, the semi-domesticated dog population in Bangkok is approximately 140,000 . Poor hygiene practices and overpopulation of these dogs will most likely increase the rates of disease 
transmission. These dogs serve as reservoirs for several parasites such as Strongyloides spp., Trichuris spp., and Ancylostoma spp., which can cause zoonotic diseases in humans. In Thailand, semi-domesticated dogs residing in temples live close to humans, which are consequently a potential reservoir for hookworms.

In the present study, we aimed to determine the prevalence and genotype of hookworms and to elucidate the risk factors associated with hookworm infections in semi-domesticated dogs residing in temples in Bangkok using molecular techniques.

\section{Materials and Methods}

\section{Ethical approval}

This study was approved by the Animal Ethics Committee of Kasetsart University, Bangkok (ACKU60-VET-006).

\section{Study area, study period and sample collection}

The sampling was conducted between June to December 2015. The Bureau of Disease Control and Veterinary Services reported stray dog population of 720,000 dogs (z) in Bangkok using the statistical theory. Using the formula $\mathrm{n}=\frac{\mathrm{N}}{1+\mathrm{N}\left(\mathrm{e}^{2}\right)}(\mathrm{N}=720,000$; $\mathrm{e}=0.05$ ), a sample size (n) of 394 was determined. However, it was decided to collect 500 samples for better representation and to account for rejected samples. The selection of temples for sample collection in Bangkok was performed in such a manner as to maximize the range of sample collection and the degree to which it represented the sample population. The districts in Bangkok differ in terms of area and population size as well as the number of temples. In other words, a single temple was sampled in a small district, whereas 2-3 temples were sampled in a bigger district, with 5-10 dogs being sampled in each temple. A fecal sample was collected from the rectum of individual dogs, transferred to a plastic bag, and maintained in a cool condition during transportation. All fecal samples were transported to the Department of Parasitology, Faculty of Veterinary Medicine, Kasetsart University, and screened for hookworms using molecular techniques. Furthermore, to record information about each dog, monks or animal caretakers were asked to complete a questionnaire related to the dog's environment and hygiene, including the following questions: Can the dog roam freely around the temple? Does the dog receive attention from a veterinarian? and Does the dog receive vaccines or deworming program?

\section{DNA extraction}

Genomic DNA was extracted directly from $200 \mathrm{mg}$ fecal samples using a commercially available DNA extraction kit (E.Z.N.A. ${ }^{\circledR}$ Stool DNA Kit, Omega Bio-Tek Inc., Norcross, GA, USA) according to the manufacturer's instructions. The final elution of DNA was prepared in $100 \mathrm{ml}$ of elution buffer. All extracted DNA samples were stored at $-20^{\circ} \mathrm{C}$ until polymerase chain reaction (PCR) analysis.

\section{Molecular characterization of hookworm species}

Diagnostic PCR-restriction fragment length polymorphism (RFLP) characterization of canine hookworms was performed as described previously $[9,14,19,20]$. The internal transcribed spacer (ITS)regions ITS1, 5.8S, and ITS2 were used to amplify $545 \mathrm{bp}$ of Ancylostoma genome using the primers RTGHFI (5'-CGTGCTAGTCTTCAGGACTTTG-3') and RTABCR1 (5'-CGGGAATTGCTATAAGCAAG TGC-3'). The final reaction volume of PCR was $20 \mu \mathrm{l}$ containing 1.25 pmol of each primer, $1 \mathrm{U}$ of iTaq DNA polymerase, $10 \times$ PCR buffer, and $2 \mu \mathrm{l}$ of DNA. The PCR conditions included heating at $94^{\circ} \mathrm{C}$ for $2 \mathrm{~min}, 64^{\circ} \mathrm{C}$ for $1 \mathrm{~min}$, and $72^{\circ} \mathrm{C}$ for $2 \mathrm{~min}$, followed by 50 cycles at $94^{\circ} \mathrm{C}$ for $30 \mathrm{~s}, 64^{\circ} \mathrm{C}$ for $30 \mathrm{~s}, 72^{\circ} \mathrm{C}$ for $30 \mathrm{~s}$, and a final extension step at $72^{\circ} \mathrm{C}$ for $7 \mathrm{~min}$. The amplified PCR products of RTGHF1-RTABCR1 were digested with Rsal to separate Ancylostoma tubaeforme from $A$. ceylanicum and A. caninum, and $H i n F 1$ was used to differentiate $A$. caninum from A. ceylanicum. Next, $10 \mu \mathrm{l}$ of the PCR product was digested with 5 units of a restriction endonuclease at $37^{\circ} \mathrm{C}$ for $6 \mathrm{~h}$ in a total volume of $20 \mathrm{ml}[9,14,21]$. The RFLP profiles of each sample were compared with the expected RFLP profiles for each hookworm species.

\section{PCR and DNA sequencing of cox1 in A. ceylanicum}

A. ceylanicum-positive samples according to PCR-PFLP were further characterized by amplification of the mitochondrial gene $(\operatorname{cox} 1)$ at the haplotype level [9,22]. A 377 bp fragment of coxl in A. ceylanicum was amplified using AceyCOX1F (5'-GCTTTTGGTATTGTA-AGACAG-3') and AceyCOX1R (5'- CTAACAACATAATAAGTATCATG-3'). The final reaction volume of PCR of $20 \mu$ contained 1.25 pmol of each primer, $1 \mathrm{U}$ of iTaq DNA polymerase, $10 \times$ PCR buffer, and $2 \mu \mathrm{l}$ of DNA. The cycling conditions were $95^{\circ} \mathrm{C}$ for $5 \mathrm{~min}$, followed by 50 cycles at $94^{\circ} \mathrm{C}$ for $30 \mathrm{~s}, 58^{\circ} \mathrm{C}$ for $30 \mathrm{~s}, 72^{\circ} \mathrm{C}$ for $30 \mathrm{~s}$, and a final extension step at $72^{\circ} \mathrm{C}$ for $7 \mathrm{~min}$ [9]. Positive samples obtained on PCR were purified using the FavorPrep ${ }^{\mathrm{TM}}$ GEL/PCR Purification Kit (Favorgen Biotech Corporation, Ping-Tung, Taiwan) and submitted for sequencing to AITbiotech (AITbiotech Pte. Ltd., Singapore).

\section{Phylogenetic analysis}

DNA sequencing was performed using FinchTV version 1.4.0, and the results were analyzed using BLAST (National Center for Biotechnology Information). DNA sequences were aligned with coxl sequences using BioEdit version 7.2.5. Neighbor-joining method was conducted using Tamura-Nei parameter distance estimates, and a phylogenetic tree was constructed using Mega 6 (Pennsylvania State University, Pennsylvania, USA) (www.megasoftware.net). Bootstrap analyses were performed using 1000 replicates.

\section{Statistical analysis}

$\mathrm{R}$ version 3.4.2 was used for data entry and statistical analyses. Data regarding the prevalence 
of hookworm infections were summarized using cross-tabulations. Univariate analysis was performed using logistic multiple regression with $95 \%$ confidence interval (CI) to determine the association between the presence of hookworm pathogens and putative risk factors such as host factors (sex and age) and location (zone).

\section{Results}

\section{Prevalence of hookworm infection}

According to the results of the PCR-based amplification of the partial ITS gene, the prevalence of hookworm infections was only $6.2 \%(n=31)$ among the 500 semi-domesticated dogs. Hookworm infections were detected in temple-community dogs in 12 of the 48 districts (25.0\%; Figure-1), with Lak Si district having the highest proportion of hookworm-infected dogs $(53.8 \%)$ followed by Klong San (33.33\%) and Lat Krabang districts (27.78\%; Table-1).

\section{Molecular characterization of hookworm species}

According to the molecular characterization of hookworm species by RFLP, 21 of the 31 positive samples were infected with $A$. ceylanicum $(67.7 \%)$ and 10 with $A$. caninum (32.3\%).

\section{Phylogenetic analysis of cox 1 in A. ceylanicum}

A $377 \mathrm{bp}$ fragment of the cytochrome c oxidase subunit from the above-mentioned 21 samples positive for A. ceylanicum was amplified and subjected to DNA sequencing and subsequent phylogenetic analysis. The phylogenetic tree separated into three clusters with $A$. ceylanicum grouped together and distinct from
A. caninum (GenBank accession no. NC02309) and A. duodenale (GenBank accession no. NC003415). A. ceylanicum group comprised a mixture of isolates from previously reported human isolates from Malaysia (GenBank accession nos. KC247737 and KC247745) and Cambodia (GenBank accession nos. KF896601 and KF896605) and in dog isolates from Malaysia (GenBank accession no. KC247730), Cambodia (GenBank accession no. KF896596), and Thailand (GenBank accession no. KF896595). Characterization of coxl in A. ceylanicum isolates revealed the presence of a mixture of human and dog isolates in all positive samples (Figure-2).

\section{Risk factors associated with hookworm infections in semi-domesticated dogs}

Multiple logistic regression analysis of risk factors revealed an increased risk of hookworm infections in dogs living in the suburbs of Bangkok $(\mathrm{p}<0.0001$, odds ratio $=4.55,95 \% \mathrm{CI}=1.98-10.47)$. Although the prevalence of hookworm infections was the highest in dogs aged $<1$ year and male dogs, no significant associations were detected between the prevalence of hookworm infections and age group, sex, household, and hygiene practices (Table-2).

\section{Discussion}

We found a relatively low prevalence $(6.2 \%)$ of hookworm infections in Thailand, which is lower than that reported previously in temple dogs in Bangkok (58.0\%) [14], shelter dogs in Nakhon Nayok (30.6\%) [13], and dogs in lower Northern Thailand $(21.3 \%)$ [15] as well as in China $(20.2 \%)$ [23,24],

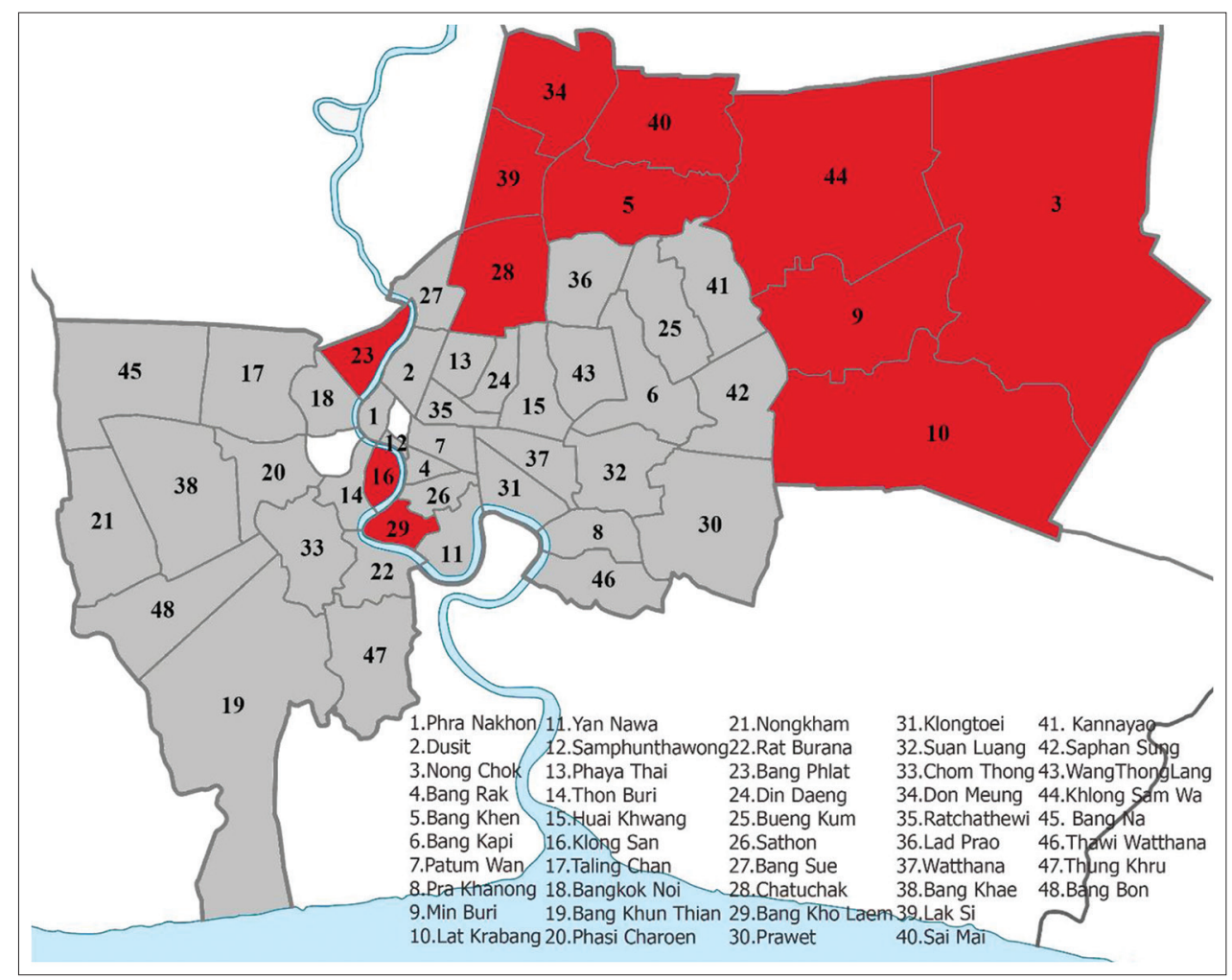

Figure-1: Map of hookworm-infected districts (red areas) and non-infected districts (gray areas) in Bangkok, Thailand [Source: https://upload.wikimedia.org/wikipedia/commons/4/4f/Thailand_Bangkok_location_map.png]. 
Table-1: Prevalence of hookworm spp. infections in semi-domesticated dogs residing in monasteries of Bangkok.

\begin{tabular}{|c|c|c|}
\hline District & Number of dogs & $\begin{array}{c}\text { Number of } \\
\text { positive }(\%)\end{array}$ \\
\hline Lak Si & 13 & $7(53.8)$ \\
\hline Klong San & 6 & $2(33.33)$ \\
\hline Lat Krabang & 18 & $5(27.78)$ \\
\hline Bang Kho Laem & 4 & $1(25.00)$ \\
\hline Don Mueang & 13 & $3(23.07)$ \\
\hline Min Buri & 7 & $1(14.28)$ \\
\hline Bang Khen & 53 & $7(13.20)$ \\
\hline Nong Chok & 8 & $1(12.50)$ \\
\hline Bang Phlat & 9 & $1(11.11)$ \\
\hline Chatuchak & 11 & $1(9.09)$ \\
\hline Sai Mai & 20 & $1(5.00)$ \\
\hline Klong Sam Wa & 21 & $1(4.76)$ \\
\hline Lad Prao & 23 & $0(0.00)$ \\
\hline Saphan Sung & 8 & $0(0.00)$ \\
\hline Dusit & 5 & $0(0.00)$ \\
\hline Kannayao & 9 & $0(0.00)$ \\
\hline Bueng Kum & 15 & $0(0.00)$ \\
\hline Phaya Thai & 10 & $0(0.00)$ \\
\hline Ratchathewi & 10 & $0(0.00)$ \\
\hline Samphanthawong & 4 & $0(0.00)$ \\
\hline Sathon & 12 & $0(0.00)$ \\
\hline Phra Khanong & 7 & $0(0.00)$ \\
\hline Bang Kapi & 12 & $0(0.00)$ \\
\hline Bang $\mathrm{Na}$ & 13 & $0(0.00)$ \\
\hline Bang sue & 12 & $0(0.00)$ \\
\hline Bang Khae & 13 & $0(0.00)$ \\
\hline Nongkham & 12 & $0(0.00)$ \\
\hline Prawet & 16 & $0(0.00)$ \\
\hline Taling Chan & 9 & $0(0.00)$ \\
\hline Rat Burana & 9 & $0(0.00)$ \\
\hline Khlong Toei & 5 & $0(0.00)$ \\
\hline Bangkok Noi & 5 & $0(0.00)$ \\
\hline Huai Khwang & 9 & $0(0.00)$ \\
\hline Bang Bon & 4 & $0(0.00)$ \\
\hline Chom Thong & 7 & $0(0.00)$ \\
\hline Thung Khru & 16 & $0(0.00)$ \\
\hline Phasi Charoen & 7 & $0(0.00)$ \\
\hline Thawi Watthana & 3 & $0(0.00)$ \\
\hline Bang Khun Thian & 12 & $0(0.00)$ \\
\hline Din Daeng & 7 & $0(0.00)$ \\
\hline Thon Buri & 11 & $0(0.00)$ \\
\hline Suan Luang & 2 & $0(0.00)$ \\
\hline Watthana & 3 & $0(0.00)$ \\
\hline Yan Nawa & 11 & $0(0.00)$ \\
\hline Wang Thong Lang & 2 & $0(0.00)$ \\
\hline Bang Rak & 3 & $0(0.00)$ \\
\hline Phra Nakhon & 7 & $0(0.00)$ \\
\hline Pathum Wan & 4 & $0(0.00)$ \\
\hline Total & 500 & $31(6.2)$ \\
\hline
\end{tabular}

Laos (94.0\%) [10], Malaysia (48.0-71.1\%) [11,12], and Cambodia (95.7\%) [9]. This finding confirmed that hookworms are pathogens that infect semi-domesticated dogs in Bangkok. The majority of semi-domesticated dogs live outdoors and roam freely, and they shed parasite eggs in public areas by which healthy animals and humans may become susceptible to infections. The previous studies have also reached a similar conclusion regarding parasites in dogs [25] and cats [26] as well as on temple grounds [27] in Bangkok. These studies have reported that 6 of 12 positive districts are in the suburban area and most of the infected districts are located adjacent to the neighboring provinces of Bangkok. These results provide important information about the presence of dog-related hookworms that may spread on temple grounds of these districts.

A case each of human hookworm infection was reported from Chachoengsao [28], Khon Kaen, and Nakhon Si Thammarat [29] as well as among Myanmar refugees living in camps along the Myanmar-Thailand border [30]. $N$. americanus was the most common hookworm species, with A. ceylanicum also being detected. Our findings strongly support the findings of the previous studies [9,24,31], demonstrating that the primary culprit of hookworm infections in semi-domesticated dogs was A. ceylanicum, which is one of the neglected parasitic zoonoses followed by A. caninum [32]. A. ceylanicum is an endemic and widely distributed hookworm species found in dogs and cats in Asia. Moreover, it can easily infect the intestine of human adults [33], leading to the development of eosinophilia, iron deficiency anemia, abdominal pain, and bloody diarrhea [23,34-36].

Based on molecular epidemiological data obtained from the characterization of coxl in A. ceylanicum, the isolates could be divided into two genetically distinct groups, with the first clade comprising isolates from humans, dogs, and cats and the second clade specific to humans [25,37]. All 21 A. ceylanicum hookworm isolates from dogs in our study grouped strongly within the zoonotic haplotype of $A$. ceylanicum within a subgroup comprising dog and human isolates from Malaysia, Cambodia, and Thailand; this confirmed that the transmission from dogs to humans follows the pattern established in a previous study [9].

Analysis of the risk factors for hookworm infections in humans in Thailand revealed walking barefoot and raising buffalos near the house to be definite significant risk factors [29]. Our study demonstrated that dogs living in the suburbs of Bangkok are more likely to be infected than those living in other zones (inner city and urban fringe), which is perhaps due to poor hygiene in the suburbs and nearby provinces. However, no study has confirmed this theory because in the study by Traub et al. [14], data were not analyzed according to location. However, we believe that this is a possible explanation for the importance of temple location as a risk factor. Further study is required to compare the distribution of hookworm infections in Bangkok. The grounds of suburban temples are generally plain, whereas city temples have cement surfaces. Because people walk barefoot and dogs defecate everywhere, the waste could more easily seep into the soil and contaminate it more than through cement ground, thereby increasing the chances of infection. These findings suggest that hygiene practices such as removal of feces and dog health care are important for the prevention and control of hookworm infections. It is necessary to conduct further 


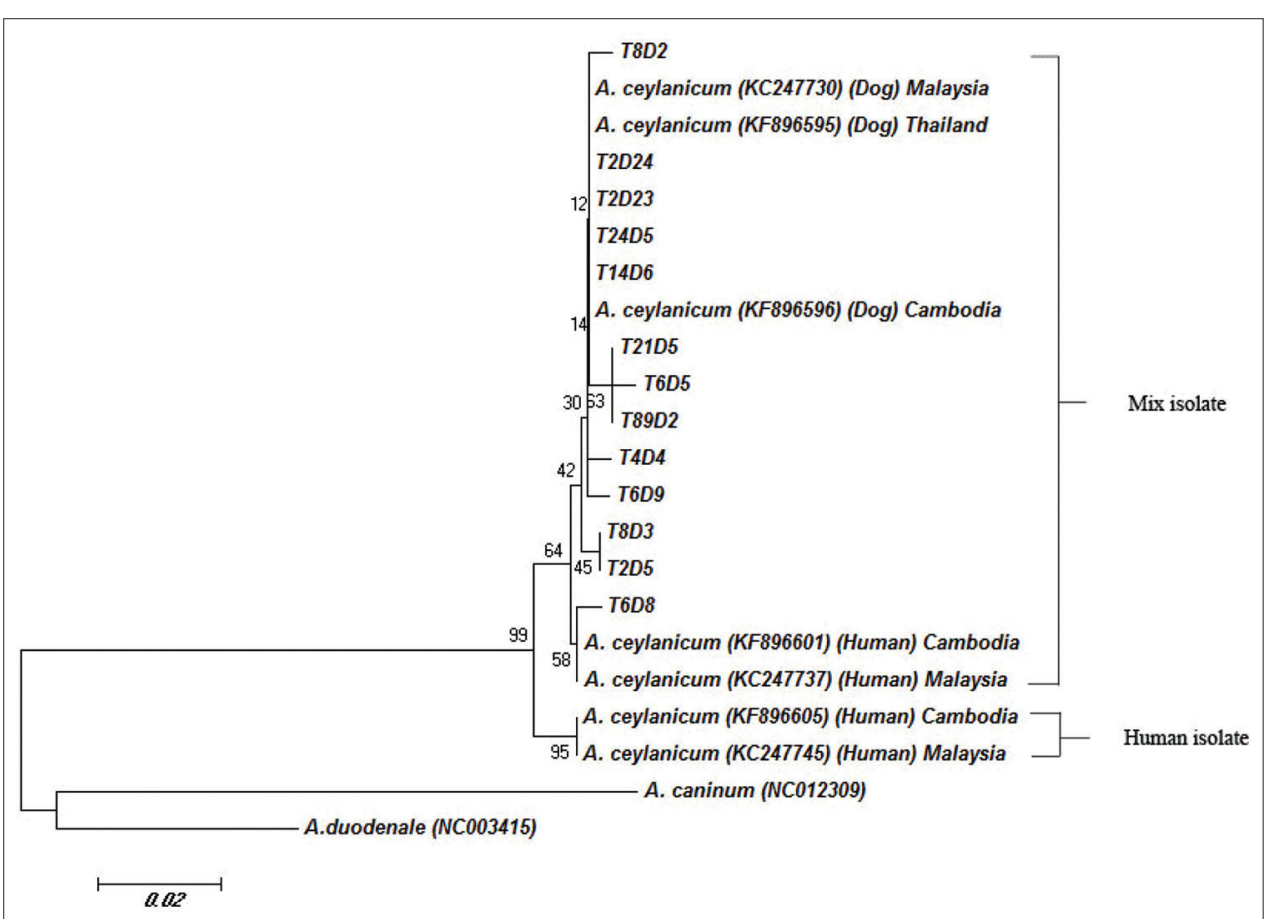

Figure-2: Phylogenetic analysis of hookworm based on the nucleotide sequences of a 377 bp fragment of cox 1 gene by the neighbor-joining method.

Table-2: Risk factors associated with hookworm infection.

\begin{tabular}{|c|c|c|c|c|c|c|}
\hline \multirow[t]{2}{*}{ Factors } & \multirow[t]{2}{*}{ Number of dogs } & \multirow{2}{*}{$\begin{array}{c}\text { Number of positive } \\
\text { (\% positive) }\end{array}$} & \multirow[t]{2}{*}{$\mathbf{p}$} & \multirow[t]{2}{*}{ Odds ratio } & \multicolumn{2}{|c|}{$95 \% \mathrm{CI}$} \\
\hline & & & & & Lower & Upper \\
\hline Sex & & & 0.205 & 0.61 & 0.29 & 1.31 \\
\hline Male & 212 & $17(8.0)$ & & & & \\
\hline Female & 288 & $14(4.8)$ & & & & \\
\hline Total & 500 & $31(6.2)$ & & & & \\
\hline Age & & & 0.307 & 0.71 & 0.37 & 1.37 \\
\hline$<1$ year & 59 & $7(11.8)$ & & & & \\
\hline $1-5$ years & 310 & $18(5.8)$ & & & & \\
\hline$>5$ years & 131 & $6(4.5)$ & & & & \\
\hline Total & 500 & $31(6.2)$ & & & & \\
\hline Free-roaming & & & 0.835 & 0.92 & 0.43 & 1.98 \\
\hline Yes & 268 & $16(5.9)$ & & & & \\
\hline No & 232 & $15(6.4)$ & & & & \\
\hline Total & 500 & $31(6.2)$ & & & & \\
\hline Veterinary attention & & & 0.338 & 1.64 & 0.59 & 4.54 \\
\hline Yes & 361 & $22(6.0)$ & & & & \\
\hline No & 139 & $9(6.4)$ & & & & \\
\hline Total & 500 & $31(6.2)$ & & & & \\
\hline Rabies vaccine & & & 0.056 & 0.33 & 0.10 & 1.03 \\
\hline Yes & 344 & $26(7.5)$ & & & & \\
\hline No & 156 & $5(0.03)$ & & & & \\
\hline Total & 500 & $31(6.2)$ & & & & \\
\hline Dewormed & & & 0.628 & 1.27 & 0.481 & 3.361 \\
\hline Yes & 123 & $6(4.8)$ & & & & \\
\hline No & 377 & $25(6.6)$ & & & & \\
\hline Total & 500 & $31(6.2)$ & & & & \\
\hline Location & & & 0.0001 & 4.55 & 1.98 & 10.47 \\
\hline Suburban & 120 & $18(15)$ & & & & \\
\hline Urban fringe & 241 & $9(3.73)$ & & & & \\
\hline Inner city & 139 & $4(2.87)$ & & & & \\
\hline Total & 500 & $31(6.2)$ & & & & \\
\hline
\end{tabular}

studies in humans and other animals such as cats as well as obtain environmental samples to explore the relationship among humans, animals, and the environment with regard to hookworm infections.

\section{Conclusion}

This study has provided important information regarding the status and risk of hookworm infections among semi-domesticated dogs in Bangkok. To the 
best of our knowledge, our study is among the first few studies to amplify coxl, to describe the subspecies of A. ceylanicum, which is a zoonotic isolate from semi-domesticated dogs residing in temples, and to provide evidence showing that semi-domesticated dogs act as a potential source of hookworm infections to human and animal populations in Bangkok. Therefore, it would be important to focus on the importance of zoonotic ancylostomiasis, and a "one health" approach should be adopted to control and prevent hookworm infections in Thailand.

\section{Authors' Contributions}

TI planned and designed the experiment and JW conducted the experiment and interpreted the results and data analysis. All authors drafted and revised the manuscript. All authors read and approved the final manuscript.

\section{Acknowledgments}

The authors would like to thank the monks, nuns, and animal caretakers for their help during sample collection. The authors acknowledge the contribution and support by staff and graduate students from the Department of Parasitology, Faculty of Veterinary Medicine, Kasetsart University, Bangkok, Thailand. This research was supported by the Center of Excellence on Agricultural Biotechnology, Science and Technology Postgraduate Education and Research Development Office, Office of Higher Education Commission, Ministry of Higher Education, Science, Research and Innovation, Thailand (AG-BIO/PERDO$\mathrm{CHE}$ ) with grant number AG-BIO/60-004-002.

\section{Competing interests} interests.

The authors declare that they have no competing

\section{Publisher's Note}

Veterinary World remains neutral with regard to jurisdictional claims in published map and institutional affiliation.

\section{References}

1. Hotez, P.J. and Kamath, A. (2009) Neglected tropical diseases in Sub-Saharan Africa: Review of their prevalence, distribution, and disease burden. PLoS Negl. Trop. Dis., 3(8): e412-e412.

2. Hossain, M. and Bhuiyan, J.U. (2017) Hookworm infection: A neglected tropical disease of mankind. J. Adv. Vet. Anim. Res., 3(4): 297-320.

3. Periago, M.V. and Bethony, J.M. (2012) Hookworm virulence factors: Making the most of the host. Microbes Infect., 14(15): 1451-1464.

4. de Silva, N.R., Brooker, S., Hotez, P.J., Montresor, A., Engels, D. and Savioli, L. (2003) Soil-transmitted helminth infections: Updating the global picture. Trends Parasitol., 19(12): 547-551.

5. Thompson, R.C.A. (2015) Neglected zoonotic helminths: Hymenolepis nana, Echinococcus canadensis and Ancylostoma ceylanicum. Clin. Microbiol. Infect., 21(5): 426-432.

6. Savilla, T.M., Joy, J.E., May, J.D. and Somerville, C.C.
(2011) Prevalence of dog intestinal nematode parasites in South central West Virginia, USA. Vet. Parasitol., 178(1-2): 115-120.

7. Smout, F.A., Skerratt, L.F., Butler, J.R.A., Johnson, C.N., Congdon, B.C. and Thompson, R.C.A. (2017) The hookworm Ancylostoma ceylanicum: An emerging public health risk in Australian tropical rainforests and Indigenous communities. One Health, 3(2017): 66-69.

8. George, S., Levecke, B., Kattula, D., Velusamy, V., Roy, S., Geldhof, P., Sarkar, R. and Kang, G. (2016) Molecular identification of hookworm isolates in humans, dogs and soil in a tribal area in Tamil Nadu, India. PLoS Negl. Trop. Dis., 10(8): e0004891-e0004891.

9. Inpankaew, T., Schär, F., Dalsgaard, A., Khieu, V., Chimnoi, W., Chhoun, C., Sok, D., Marti, H., Muth, S., Odermatt, P. and Traub, R.J. (2012) High prevalence of Ancylostoma ceylanicum hookworm infections in humans, Cambodia. Emerg. Infect. Dis., 20(6): 976-982.

10. Conlan, J.V., Khamlome, B., Vongxay, K., Elliot, A., Pallant, L., Sripa, B., Blacksell, S.D., Fenwick. S. and Thompson, R.C. (2012) Soil-transmitted helminthiasis in Laos: A community-wide cross-sectional study of humans and dogs in a mass drug administration environment. Am. J. Trop. Med. Hyg., 86(4): 624-634.

11. Mahdy, M.A., Lim, Y.A., Ngui, R., Fatimah, M.R.S., Choy, S.H., Yap, N.J., Al-Mekhlafi, H.M., Ibrahim, J. and Surin, J. (2012) Prevalence and zoonotic potential of canine hookworms in Malaysia. Parasites Vectors, 5(1): 88.

12. Ngui, R., Lim, Y.A., Traub, R., Mahmud, R. and Mistam, M.S. (2012) Epidemiological and genetic data supporting the transmission of Ancylostoma ceylanicum among human and domestic animals. PLoS Negl. Trop. Dis., 6(2): e1522.

13. Rojekittikhun, W., Chaisiri, K., Mahittikorn, A., Pubampen, S., Sa-Nguankiat, S., Kusolsuk, T., Maipanich, W., Udonsom, R. and Mori, H. (2014) Gastrointestinal parasites of dogs and cats in a refuge in Nakhon Nayok, Thailand. Southeast Asian J. Trop. Med. Public Health, 45(1): 31-39.

14. Traub, R.J., Inpankaew, T., Sutthikornchai, C., Sukthana, Y. and Thompson, R.C. (2008) PCR-based coprodiagnostic tools reveal dogs as reservoirs of zoonotic ancylostomiasis caused by Ancylostoma ceylanicum in temple communities in Bangkok. Vet. Parasitol., 155(1): 67-73.

15. Pumidonming, W., Salman, D., Gronsang, D., Abdelbaset, A.E., Sangkaeo, K., Kawazu, S.I. and Igarashi, M. (2017) Prevalence of gastrointestinal helminth parasites of zoonotic significance in dogs and cats in lower Northern Thailand. J. Vet. Med. Sci., 78(12): 1779-1784.

16. Seguel, M. and Gottdenker, N. (2017) The diversity and impact of hookworm infections in wildlife. Int. J. Parasitol., 6(3): 177-194.

17. Xie, Y., Hoberg, E.P., Yang, Z., Urban, J.F. Jr. and Yang, G. (2017) Ancylostoma ailuropodae n. sp. (Nematoda: Ancylostomatidae), a new hookworm parasite isolated from wild giant pandas in Southwest China. Parasites Vectors, 10(1): 277-277.

18. Smout, F.A., Thompson, R.C.A. and Skerratt, L.F. (2013) First report of Ancylostoma ceylanicum in wild canids. Int. J. Parasitol., 2(2013): 173-177.

19. Traub, R., Hobbs, R.P., Adams, P.J., Behnke, J.M., Harris, P.D. and Thompson, R.C. (2007) A case of mistaken identity-reappraisal of the species of canid and felid hookworms (Ancylostoma) present in Australia and India. Parasitology, 134(Pt 1): 113-119.

20. Papaiakovou, M., Pilotte, N., Grant, J.R., Traub, R.J., Llewellyn, S., McCarthy, J.S., Krolewiecki, A.J., Cimino, R., Mejia, R. and Williams, S.A. (2017) A novel, species-specific, real-time PCR assay for the detection of the emerging zoonotic parasite Ancylostoma ceylanicum in human stool. PLoS Negl. Trop. Dis., 11(7): e0005734.

21. Palmer, C.S., Traub, R.J., Robertson, I.D., Hobbs, R.P., 
Elliot, A., While, L., Rees, R. and Thompson, R.C. (2007) The veterinary and public health significance of hookworm in dogs and cats in Australia and the status of A. ceylanicum. Vet. Parasitol., 145(3): 304-313.

22. Ngui, R., Mahdy, M.A., Chua, K.H., Traub, R. and Lim, Y.A. (2013) Genetic characterization of the partial mitochondrial cytochrome oxidase c subunit I ( $\operatorname{cox} 1)$ gene of the zoonotic parasitic nematode, Ancylostoma ceylanicum from humans, dogs and cats. Acta Trop., 128(1): 154-157.

23. Liu, Y.J., Zheng, G.C., Zhang, P., Alsarakibi, M., Zhang, X.H., Li, Y.W., Liu, T., Ren, S.N., Chen, Z.X., Liu, Y.L., Li, S.J. and Li, G.Q. (2015) Molecular identification of hookworms in stray and shelter dogs from Guangzhou city, China using ITS sequences. J. Helminthol., 89(2): 196-202.

24. Fu, Y., Huang, Y., Abuzeid, A.M.I., Hang, J., Yan, X., Wang, M., Liu, Y., Sun, Y., Ran, R., Zhang, P. and Li, G. (2019) Prevalence and potential zoonotic risk of hookworms from stray dogs and cats in Guangdong, China. Vet. Parasitol. Reg. Stud. Reports., 17(2019): 100316.

25. Inpankaew, T., Traub, R., Thompson, R.C. and Sukthana, Y. (2007) Canine parasitic zoonoses in Bangkok temples. Southeast Asian J. Trop. Med. Public Health, 38(2): 247.

26. Jittapalapong, S., Inparnkaew, T., Pinyopanuwat, N., Kengradomkij, C., Sangvaranond, A. and Wongnakphet, S. (2007) Gastrointestinal parasites of stray cats in Bangkok metropolitan areas Thailand. Kasetsart J. Nat. Sci., 41(5): 69-73.

27. Pinyopanuwat, N., Kengradomkij, C., Kamyingkird, K., Chimnoi, W., Suraruangchai, D. and Inpankaew, T. (2018) Stray animals (dogs and cats) as sources of soil-transmitted parasite eggs/cysts in temple grounds of Bangkok metropolitan, Thailand. J. Trop. Med. Parasitol., 41(1-2): 15-20.

28. Jiraanankul, V., Aphijirawat, W., Mungthin, M., Khositnithikul, R., Rangsin, R., Traub, R.J., Piyaraj, P., Naaglor, T., Taamasri, P. and Leelayoova, S. (2011) Incidence and risk factors of hookworm infection in a rural community of central Thailand. Am. J. Trop. Med. Hyg., 84(4): 594-598.
29. Phosuk, I., Intapan, P.M., Thanchomnang, T., Sanpool, O., Janwan, P., Laummaunwai, P., Aamnart, W., Morakote, N. and Maleewong, W. (2013) Molecular detection of Ancylostoma duodenale, Ancylostoma ceylanicum, and Necator americanus in humans in Northeastern and Southern Thailand. Korean J Parasitol., 51(6): 747-749.

30. O'Connell, E.M., Mitchell, T., Papaiakovou, M., Pilotte, N., Lee, D., Weinberg, M., Sakulrak, P., Tongsukh, D., OduroBoateng, G., Harrison, S., Williams, S.A., Stauffer, W.M. and Nutman, T.M. (2018) Ancylostoma ceylanicum hookworm in myanmar refugees, Thailand, 2012-2015. Emerg. Infect. Dis., 24(8): 1472.

31. Tun, S., Ithoi, I., Mahmud, R., Samsudin, N.I., Heng, C.K. and Ling, L.Y. (2015) Detection of helminth eggs and identification of hookworm species in stray cats, dogs and soil from Klang Valley, Malaysia. PLoS One, 10(12): 1-12.

32. Traub, R.J. (2013) Ancylostoma ceylanicum, a re-emerging but neglected parasitic zoonosis. Int. J. Parasitol., 43(12): 1009-1015.

33. Bowman, D.D., Montgomery, S.P., Zajac, A.M., Eberhard, M.L. and Kazacos, K.R. (2010) Hookworms of dogs and cats as agents of cutaneous larva migrans. Trends Parasitol., 26(4): 162-167.

34. Hotez, P.J., Brooker, S., Bethony, J.M., Bottazzi, M.E., Loukas, A. and Xiao, S. (2004) Hookworm infection. N. Engl. J. Med., 351(8): 799-807.

35. Liu, Y.J., Zheng, G., Alsarakibi, M., Zhang, X., Hu, W., Lin, L., Tan, L., Luo, Q., Lu, P. and Li, G. (2014) The zoonotic risk of Ancylostoma ceylanicum isolated from stray dogs and cats in Guangzhou, South China. Biomed Res. Int., 2014: 1-5.

36. Brunet, J., Lemoine, J.P., Lefebvre, N., Denis, J., Pfaff, A.W., Abou-Bacar, A., Traub, R.J., Pesson, B. and Candolfi, E. (2015) Bloody diarrhea associated with hookworm infection in traveler returning to France from Myanmar. Emerg. Infect. Dis., 21(10): 1878-1879.

37. Ng-Nguyen, D., Hii, S.F., Nguyen, A.V.T., Van Nguyen, T., Van Nguyen, D. and Traub, R.J. (2015) Re-evaluation of the species of hookworms infecting dogs in Central Vietnam. Parasites Vectors, 8: 401. 